\title{
Correction: effect of low tidal ventilation on lung function and inflammation in mice
}

Hans P Hauber ${ }^{1,2^{*}}$, Dörte Karp ${ }^{1}$, Torsten Goldmann ${ }^{3}$, Ekkehard Vollmer ${ }^{3}$ and Peter Zabel ${ }^{2}$

\section{Correction}

In our publication "Effect of low tidal volume ventilation and inflammation in mice" [1] an error has occured in figure one. Due to technical limitations we were not able to measure oxygen saturation and heart rate in all animals. Unfortunately we only realized that we applied mean value and SEM when we re-checked our data because of a discussion with colleagues. We decided that it would not make sense to present mean values and the SEM because of the small numbers of animals in each group. We revised the figure (see revised Figure 1) and present now individual and mean values together with the numbers of animals that could be investigated. We apologize for any incovenience this

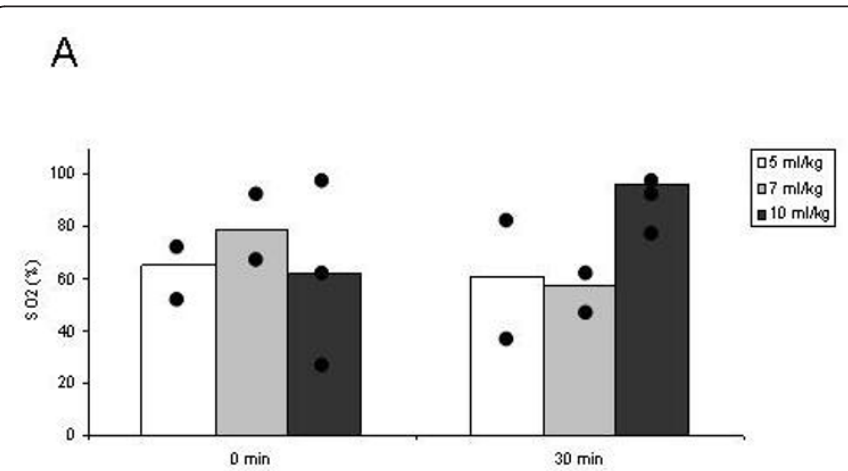

C

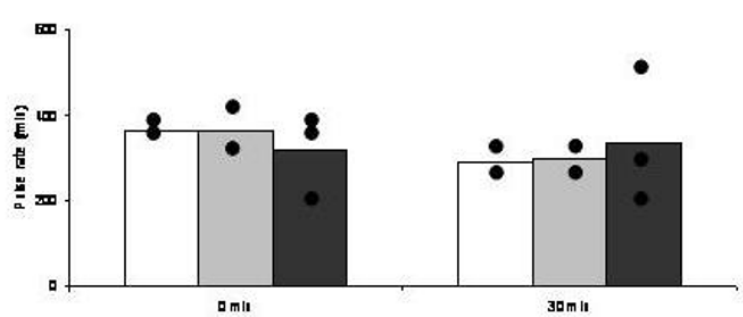

B

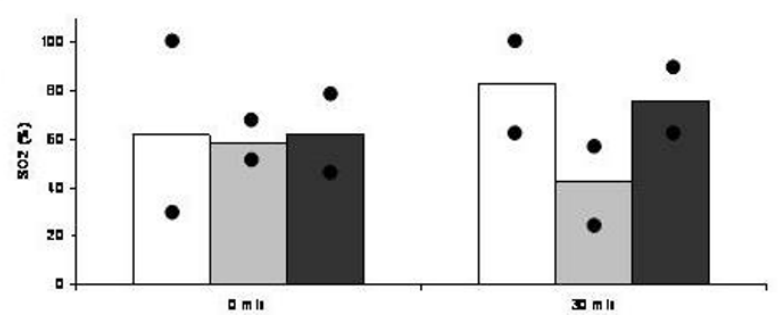

D

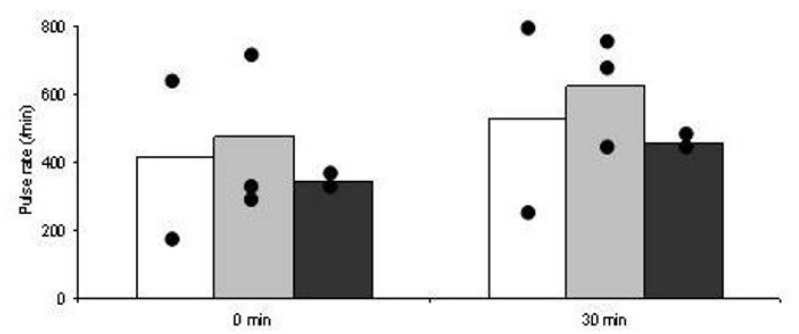

Figure 1 Oxygen saturation $(A, B)$ and pulse rate $(C, D)$ immediately after the beginning of mechanical ventilation $(0 \mathrm{~min})$ and after $30 \mathrm{~min}$ (30 $\mathrm{min}$ ) with different tidal volumes without (A, C) and with addition of PEEP (B, D). Bars represent mean values of 2 or 3 animals per group. Dots show individual values to demonstrate the high variability in measurements.

\footnotetext{
* Correspondence: hphauber@fz-borstel.de

'Division of Pathophysiology of Inflammation, Research Center Borstel,

Borstel, Germany

Full list of author information is available at the end of the article
}

(c) 2012 Hauber et al; licensee BioMed Central Ltd. This is an Open Access article distributed under the terms of the Creative Commons 
may cause. However, the overall conclusions are not affected by this change.

\section{Author details}

'Division of Pathophysiology of Inflammation, Research Center Borstel, Borstel, Germany. ${ }^{2}$ Medical Clinic, Research Center Borstel, Borstel, Germany. ${ }^{3}$ Division of Experimental Pathology, Research Center Borstel, Borstel, Germany.

Received: 15 February 2012 Accepted: 23 February 2012

Published: 23 February 2012

\section{Reference}

1. Hauber HP, Karp D, Goldmann T, Vollmer E, Zabel P: Effect of low tidal volume ventilation on lung function and inflammation in mice. $B M C$ Pulm Med 2010, 10:21.

\section{Pre-publication history}

The pre-publication history for this paper can be accessed here: http://www.biomedcentral.com/1471-2466/12/7/prepub

doi:10.1186/1471-2466-12-7

Cite this article as: Hauber et al: Correction: effect of low tidal

ventilation on lung function and inflammation in mice. BMC Pulmonary Medicine 2012 12:7.

\section{Submit your next manuscript to BioMed Central} and take full advantage of:

- Convenient online submission

- Thorough peer review

- No space constraints or color figure charges

- Immediate publication on acceptance

- Inclusion in PubMed, CAS, Scopus and Google Scholar

- Research which is freely available for redistribution

Submit your manuscript at www.biomedcentral.com/submit
() Biomed Central 